\title{
A Complementary Herbal Product for Controlling Giardiasis
}

\author{
Tarek Hamdy Abd-Elhamid 1(D), Iman A. M. Abdel-Rahman ${ }^{2}$ (D), Amany Refaat Mahmoud ${ }^{3,4}$, \\ Khaled S. Allemailem ${ }^{5}$ (D), Ahmad Almatroudi ${ }^{5}$ (D), Samer S. Fouad ${ }^{6}$, Osama H. Abdella ${ }^{7}$, \\ Hatem A. Elshabrawy $8, *$ (D) and Asmaa M. El-Kady $7, *$ (D)
}

1 Department of Histology and Cell Biology, Faculty of Medicine, Assiut University, Assiut 71515, Egypt; tabdelhamid@aun.edu.eg

2 Department of Pharmacognosy, Faculty of Pharmacy, South Valley University, Qena 83523, Egypt; emanabdelraheem@svu.edu.eg

3 Department of Human Anatomy and Embryology, Faculty of Medicine, Assiut University, Assiut 71515, Egypt; armahmoud74@gmail.com

4 Department of Basic Medical Sciences, Unaizah College of Medicine and Medical Sciences, Qassim University, Unaizah 51911, Saudi Arabia; amany.mahmoud@ucm.edu.sa

5 Department of Medical laboratories, College of Applied Medical Sciences, Qassim University, Buraydah 51452, Saudi Arabia; K.allemailem@qu.edu.sa (K.S.A.); aamtrody@qu.edu.sa (A.A.)

6 Qena University Hospital, South Valley University, Qena 83523, Egypt; samer.saad80@yahoo.com

7 Department of Medical Parasitology, Faculty of Medicine, South Valley University, Qena 83523, Egypt; osama_hussein1891@med.svu.edu.eg

8 Department of Molecular and Cellular Biology, College of Osteopathic Medicine, Sam Houston State University, Conroe, TX 77304, USA

check for updates

Citation: Abd-Elhamid, T.H.; Abdel-Rahman, I.A.M.; Mahmoud, A.R.; Allemailem, K.S.; Almatroudi, A.; Fouad, S.S.; Abdella, O.H.; Elshabrawy, H.A.; El-Kady, A.M. A Complementary Herbal Product for Controlling Giardiasis. Antibiotics 2021, 10, 477. https://doi.org/ 10.3390/antibiotics10050477

Academic Editor: William N. Setzer

Received: 24 March 2021

Accepted: 19 April 2021

Published: 21 April 2021

Publisher's Note: MDPI stays neutral with regard to jurisdictional claims in published maps and institutional affiliations.

Copyright: (C) 2021 by the authors. Licensee MDPI, Basel, Switzerland. This article is an open access article distributed under the terms and conditions of the Creative Commons Attribution (CC BY) license (https:/ / creativecommons.org/licenses/by/ $4.0 /)$.
* Correspondence: hatem.elshabrawy@shsu.edu (H.A.E.); asmaa.elkady@med.svu.edu.eg (A.M.E.-K.); Tel.: +1-(936)202-5216 (H.A.E.); +20-1020707441 (A.M.E.-K.); Fax: +1-(936)202-5260 (H.A.E.)

\begin{abstract}
Giardiasis is an intestinal protozoal disease caused by Giardia lamblia. The disease became a global health issue due to development of resistance to commonly used drugs. Since many plant-derived products have been used to treat many parasitic infestations, we aimed to assess the therapeutic utility of Artemisia annua (A. аnnиa) for giardiasis. We showed that NO production was significantly reduced whereas serum levels of IL-6, IFN- $\gamma$, and TNF- $\alpha$ were elevated in infected hamsters compared to uninfected ones. Additionally, infection resulted in increased numbers of intraepithelial lymphocytes and reduced villi heights, goblet cell numbers, and muscularis externa thickness. We also showed that inducible NO synthase (iNOS) and caspase-3 were elevated in the intestine of infected animals. However, treatment with $A$. annua significantly reduced the intestinal trophozoite counts and IEL numbers, serum IL-6, IFN- $\gamma$, and TNF- $\alpha$, while increasing NO and restoring villi heights, GC numbers, and ME thickness. Moreover, $A$. annua treatment resulted in lower levels of caspase-3, which indicates a protective effect from apoptotic cell death. Interestingly, A. апnиа therapeutic effects are comparable to metronidazole. In conclusion, our results show that A. апnиа extract is effective in alleviating infection-induced intestinal inflammation and pathological effects, which implies its potential therapeutic utility in controlling giardiasis.
\end{abstract}

Keywords: giardiasis; NO; IL-6; TNF- $\alpha$; IFN- $\gamma$

\section{Introduction}

Giardiasis is one of the most common human intestinal protozoal infections [1]. It is caused by Giardia lamblia (G. lamblia; also known as Giardia duodenalis), which is a flagellated protozoan infecting the small intestine of humans and animals [2]. Approximately 280 million people worldwide are infected with G. lamblia annually [3]. The prevalence rates were estimated at $20-30 \%$ and $2-5 \%$ in developing and developed countries, respectively [4]. In Egypt, the prevalence rate of giardiasis ranges from 10 to 35\%, making Egypt an endemic region according to the World Health Organization (WHO) [5-8]. 
Giardiasis is transmitted through the ingestion of cysts in food and water. Infection can remain asymptomatic or can present in the form of acute or chronic diarrhea that is accompanied by abdominal pain and nausea [9]. Children can also present with malabsorption and loss of weight, which may impact their cognitive abilities [10-12]. Moreover, it has been shown that giardiasis can be more severe in immunocompromised patients [13].

Pathological changes in G. lamblia-infected intestines have been described and the organism is usually found on the villus surface or between the intestinal villi [14]. Infection with G. lamblia is associated with mucosal inflammation, intraepithelial inflammatory cell infiltration, and changes in the villus architecture [15]. Additionally, increased mucus production has been observed in the intestine of an animal model of giardiasis [16]. Moreover, giardiasis induces enterocyte apoptosis which distorts the intestinal mucosal barrier $[17,18]$. Furthermore, enteric neurons and smooth muscles are affected, which leads to reduced thickness of the external muscle layer of the intestine [19].

Previous studies of giardiasis in rodents have highlighted the essential role of IL-6 in promoting immunity against G. lamblia with elevated IL-6 mRNA levels in infected mice [20]. Interestingly, IL-6-deficient mice failed to effectively clear G. lamblia infection [20,21]. IgA production in these IL-6-deficient mice was uncompromised, which suggests that IL-6 exerts its anti-giardia effect through IgA-independent mechanism. Recently, dendritic cells have been identified as producers of IL-6 that promote clearance of G. lamblia infection in mice [22,23]. Studies have shown that intestinal nitric oxide (NO), produced by nitric oxide synthase (NOSs) using arginine as the substrate, contributes to the clearance of G. lamblia trophozoites [24,25]. In fact, NO is an essential molecule in the host defense against many pathogens, including G. lamblia, due to its cytotoxicity [24,26]. Interestingly, G. lamblia trophozoites compete with the host for arginine [27], or increase the host production of arginase which breaks down arginine [28]. The previous mechanisms diminish NO production, thereby promoting the trophozoites' survival [29]. Therefore, therapeutics that promote $\mathrm{NO}$ production could be effective in controlling giardiasis.

Drugs such as furazolidone, quinacrine, paromomycin, benzimidazole compounds, 5-nitroimidazole compounds, and nitazoxanide have long been used in treatment of giardiasis [30]. However, they have been associated with undesirable effects such as gastrointestinal upset, hepatic and renal toxicity, dermatitis, leukopenia, ototoxicity, severe pancreatitis, and high incidences of congenital anomalies [31,32]. Moreover, several studies have reported resistance of G. lamblia to these compounds [33,34]. Consequently, there is an urgent need for the discovery of alternative therapeutics for giardiasis.

Medicinal plants such as Artemisia have long been used to treat various human diseases $[35,36]$. This is attributed to their bioactive natural ingredients and their high safety profile $[37,38]$. Artemisinin, the main sesquiterpene isolated from Artemisia annua (A. annua), is highly effective in the treatment of quinine-resistant malaria and is a potent antioxidant due to its high phenolic content $[39,40]$. Several studies have also shown that A. annua is effective against trypanosomiasis [41], schistosomiasis [42], toxoplasmosis [43], leishmaniasis [44,45], and coccidiosis [46]. Moreover, in vitro experiments have demonstrated the anti-giardia effect of A. annua [47].

In the current study, we evaluated the efficacy of $A$. annua in an animal model of giardiasis. We show that $A$. annua is effective in reducing G. lamblia trophozoite count, inflammation, and parasite-induced intestinal pathological changes. Interestingly, all these effects were comparable to metronidazole, the currently used anti-giardiasis drug, which suggests that $A$. annua could be a potential and safe therapeutic for giardiasis.

\section{Materials and Methods}

This study was conducted at the animal house and Medical Parasitology Department, Faculty of Medicine, South Valley University, Qena, Egypt. All experiments were performed according to the regulations of Animal Care and Use Committee at the Faculty of Medicine, South Valley University, Qena, Egypt. The study design was approved by 
the Institutional Research Committee at the Faculty of Medicine, South Valley University, Qena, Egypt.

\subsection{Animals}

Thirty-two male golden hamsters, aged 3-4 weeks and weighing 150-200 g each, were procured from the animal house at Theodore Bilharz Research Institute (TBRI), Giza, Egypt. Hamsters were bred under specified pathogen-free conditions. To ensure that hamsters were free from intestinal parasites, stool samples were examined for three consecutive days before starting the experiments

\subsection{Plant Material}

The plant material was collected during the flowering stage from a cultivated field near South Valley University. A voucher specimen of the plant (code: Aa.78) was kept in the herbarium, Department of Pharmacognosy, Faculty of Pharmacy, South Valley University, Egypt. Collected fresh plant was washed with running tap water to remove any associated soil particles. The plant was allowed to dry at room temperature before being ground into a fine powder.

\subsection{Preparation of A. annua Extract}

A. annua ethanolic extract was prepared according to the method described previously [48]. A. annua ethanolic extract was prepared by maceration of $200 \mathrm{~g}$ powdered plant material with $1 \mathrm{~L}$ of $95 \%$ ethanol. Plant material was allowed to macerate for $16 \mathrm{~h}$ at room temperature and then filtered. The process was repeated three times. The combined filtrates were evaporated to dryness in a rotary evaporator under reduced pressure to produce the crude dry ethanolic extract. The obtained dry extract $(16 \mathrm{~g})$ was stored at $4{ }^{\circ} \mathrm{C}$ for subsequent preparation of the required animal experiment doses.

\subsection{Preparation of Parasite for Infection}

G. lamblia cysts were collected from stools of patients of the outpatient clinics in the University hospitals, South Valley University, Qena, Egypt. All stool specimens were processed immediately at the parasitology laboratory. Giardia cyst viability was confirmed using $0.1 \%$ eosin vital staining. Cysts were then counted in $0.1 \mathrm{~mL}$ of sediment and the concentration process was repeated with more stool samples until the suspension contained about 10,000 viable cysts $/ \mathrm{mL}$ of phosphate-buffered saline. Animals of different groups were each infected orally with $1 \mathrm{~mL}$ of phosphate-buffered saline containing 10,000 cysts [49].

\subsection{Animal Experiments}

Animals were equally divided into 4 groups, 8 animals each. UI group included uninfected animals. Animals of IGL, metronidazole (Met) treatment positive control group, and $A$. annua (AA) group were infected with $1 \mathrm{~mL}$ phosphate-buffered saline containing 10,000 giardia cysts orally [49]. Three weeks post-infection, Met and AA animal groups were treated orally with $120 \mathrm{mg} / \mathrm{kg}$ of metronidazole for 2 successive days or $400 \mathrm{mg} / \mathrm{kg}$ A. annua ethanolic extract for 3 consecutive days, respectively [50,51]. Stainless steel esophageal tube was used to administer the treatment. Animals of all groups were then sacrificed 2 weeks after treatment, as previously reported, to evaluate the drug efficacy [50]. Doses of metronidazole and A. annua ethanolic extract were selected according to previously published reports [51,52].

\subsection{Assessment of the Efficacy of the Extract}

\subsubsection{Determination of Trophozoites Count in Different Groups of Infected Hamsters}

After sacrificing hamsters, the small bowel was removed and the duodenal contents were subjected to parasitological examination in order to count the number of G. lamblia trophozoites in five successive fields/animal as previously described [53,54]. 


\subsubsection{Quantification of Proinflammatory Cytokines and NO}

Blood samples were collected and sera were separated and stored at $-20{ }^{\circ} \mathrm{C}$ until used. Levels of NO were determined by measuring $\mathrm{NO}$ end products (NOx) in serum using Biodiagnostic colorimetric assay kit [55]. The levels of IL-6, TNF- $\alpha$, and IFN- $\gamma$ were determined using ELISA kits according to the manufacturer's protocol (Koma Biotech Inc., Cat. No. K0331229, K0331196, and K0331209, respectively).

\subsection{Histopathological Studies}

Specimens of 2-5 cm from the proximal part of the small intestine (duodenum and jejunum) removed from sacrificed hamsters were fixed in $10 \%$ formalin and embedded in paraffin. Sections of $5 \mu \mathrm{m}$ thickness were stained with hematoxylin and eosin or Periodic Acid Schiff (PAS) and hematoxylin as previously described [56].

\subsubsection{Assessment of Villi Length and Muscularis Externa Thickness}

Three animals/group were used for the assessment of these parameters. A total of 15 images of random fields/group were used. Images at 100× magnification were used for assessment of the villi length and at $400 \times$ magnification for measuring muscularis externa thickness using Fiji ImageJ software, version 1.52p.

\subsubsection{Determination of Intraepithelial Lymphocytes (IEL) and Goblet Cell Numbers}

Three animals/group were used for the assessment of IEL and goblet cell numbers. Images captured at $200 \times$ were used for assessing IEL. We counted 2500 enterocytes and IELs and then the ratios of IEL/100 enterocytes were calculated [57]. For goblet cell counts, fifteen images of random fields/animal group of sections stained with Periodic Acid Schiff (PAS) and hematoxylin were used. In each image, we counted the number of goblet cells and enterocytes and then we calculated the ratios of goblet cells/100 enterocytes

\subsubsection{Immunohistochemistry}

Paraffin sections of the small intestine of different groups were deparaffinized and rehydrated with descending percentages of ethanol. Sections were boiled in citrate buffer ( $\mathrm{pH}$ 6.0) in a microwave for epitope retrieval. Endogenous peroxidases were then blocked with $3 \% \mathrm{H}_{2} \mathrm{O}_{2}$ in ethanol. Sections were incubated with anti-caspase-3 antibodies (Thermo Scientific, Waltham, MA, USA; dilution 1:500) or anti-inducible nitric oxide synthase (iNOS) polyclonal antibodies (Thermo Scientific, USA, dilution 1:50) for $60 \mathrm{~min}$ at room temperature. Next, sections were washed with TBS containing 0.05\% Tween-20 (TBS-T). Sections were then incubated with HRP-conjugated goat anti-rabbit secondary antibodies (Vivantis Technologies, Malaysia) at a dilution of 1:5000 for $1 \mathrm{~h}$ at $4{ }^{\circ} \mathrm{C}$. After washing in TBS-T, the color was developed by incubating sections with $0.05 \%$ diaminobenzidine (DAB) and $0.01 \% \mathrm{H}_{2} \mathrm{O}_{2}$ for $3 \mathrm{~min}$. For negative control, we omitted the primary antibodies during staining of some slides. Images were captured using Leica light microscope equipped with a digital camera in the Histology and Cell Biology Department, Assiut University, Faculty of Medicine, Assiut, Egypt.

\subsection{Statistical Analysis}

The collected data were analyzed by SPSS (Statistical Package for Social Sciences), version 20 for Windows. All values were expressed as mean \pm standard deviation (SD). Differences between groups were determined using one-way ANOVA test to compare the mean values between treated and control groups for different variables by the Bonferroni post hoc test. Differences were considered significant when $p<0.05$.

\section{Results}

\subsection{A. annua Treatment Reduces G. lamblia Trophozoite Count in the Intestine}

Examination of small intestines of metronidazole (Met) and A. annua (AA) treatment groups for trophozoite count revealed that these animals had significant reductions in 
trophozoite count compared to the infected untreated group (IGL) $(98.3 \%$ and $92.5 \%$ reductions respectively) (Figure 1). These data suggest that $A$. annua extract is effective in reducing G. lamblia trophozoite count in the small intestine.



Figure 1. Treatment with A. annua reduced trophozoite counts in the small intestine of infected hamsters. Trophozoites were counted in infected untreated hamsters (IGL) and compared to counts in animals treated with metronidazole (Met) or A. annua (AA) extract. Data are expressed as mean \pm SD $(n=8)$ and were analyzed using ANOVA with Bonferroni corrections for pairwise comparison. Letter " $b$ " indicates significant reductions in trophozoite counts after treatments compared to IGL group $(p<0.001)$. Letter " $c$ " indicates a significant difference in trophozoite count between Met and AA group $(p<0.001)$.

\subsection{A. annua Treatment Induced NO and Reduced Proinflammatory Cytokines Production}

The role of NO in eradicating G. lamblia infection has been well established [24]. Therefore, we sought to quantify NO production in different animal groups by measuring $\mathrm{NO}$ end products (NOx) in serum. We found that infection with G. lamblia (IGL group) significantly reduced NO compared to uninfected animals (UI). In contrast, treatment of infected hamsters with metronidazole (Met group) significantly increased NO compared to IGL group $(p<0.001)$ and UI group $(p<0.001)$. Similarly, treatment with $A$. annua extract (AA group) significantly induced NO production compared to IGL group $(p<0.001)$. However, there was no significant difference between metronidazole and $A$. annua treatment on NO production (Figure 2a).

Next, we measured serum IL-6 levels in different animal groups. Zhou et al. previously reported increased IL-6 levels during the course of giardiasis in mice [20]. Therefore, we sought to compare the effects of metronidazole and A. annua treatments on giardiasisinduced increase in IL-6 serum levels. IL-6 was significantly higher in sera of animals infected with G. lamblia (IGL group) compared to uninfected animals (UI group) $(p<0.05)$. Treatment of infected animals with metronidazole (Met group) or A. annua extract (AA group) resulted in a significant reduction in serum IL-6 compared to IGL group $(p<0.05)$ (Figure $2 b$ ). However, metronidazole significantly reduced IL-6 when compared to $A$. annua treatment $(p<0.05)$ (Figure $2 b)$. A recent study by Pacheco et al. has demonstrated elevated IFN- $\gamma$ in children with giardiasis [58]. Therefore, we sought to compare the effects of metronidazole and $A$. annua treatments on giardiasis-induced IFN- $\gamma$. As expected, animals infected with G. lamblia (IGL group) showed significant increase in the serum IFN- $\gamma$ compared to the uninfected animals (UI group) $(p<0.05)$ (Figure 2c). On the other hand, the serum IFN- $\gamma$ levels were significantly lower in hamsters treated with metronidazole or A. annua compared to IGL group $(p<0.05)$ (Figure $2 \mathrm{c}$ ). However, similar to IL-6, serum IFN- $\gamma$ levels were significantly lower in the Met group than AA group (Figure 2c). We also investigated the serum TNF- $\alpha$ levels in infected animals treated with metronidazole 
or A. annua extract. As shown in Figure $2 \mathrm{~d}$, serum levels of TNF- $\alpha$ in IGL group were significantly elevated compared to the UI animals $(p<0.05)$. However, treating infected animals with metronidazole or $A$. annua extract significantly reduced serum TNF- $\alpha$ levels compared to the infected untreated hamsters by 4-fold and 3-fold, respectively.

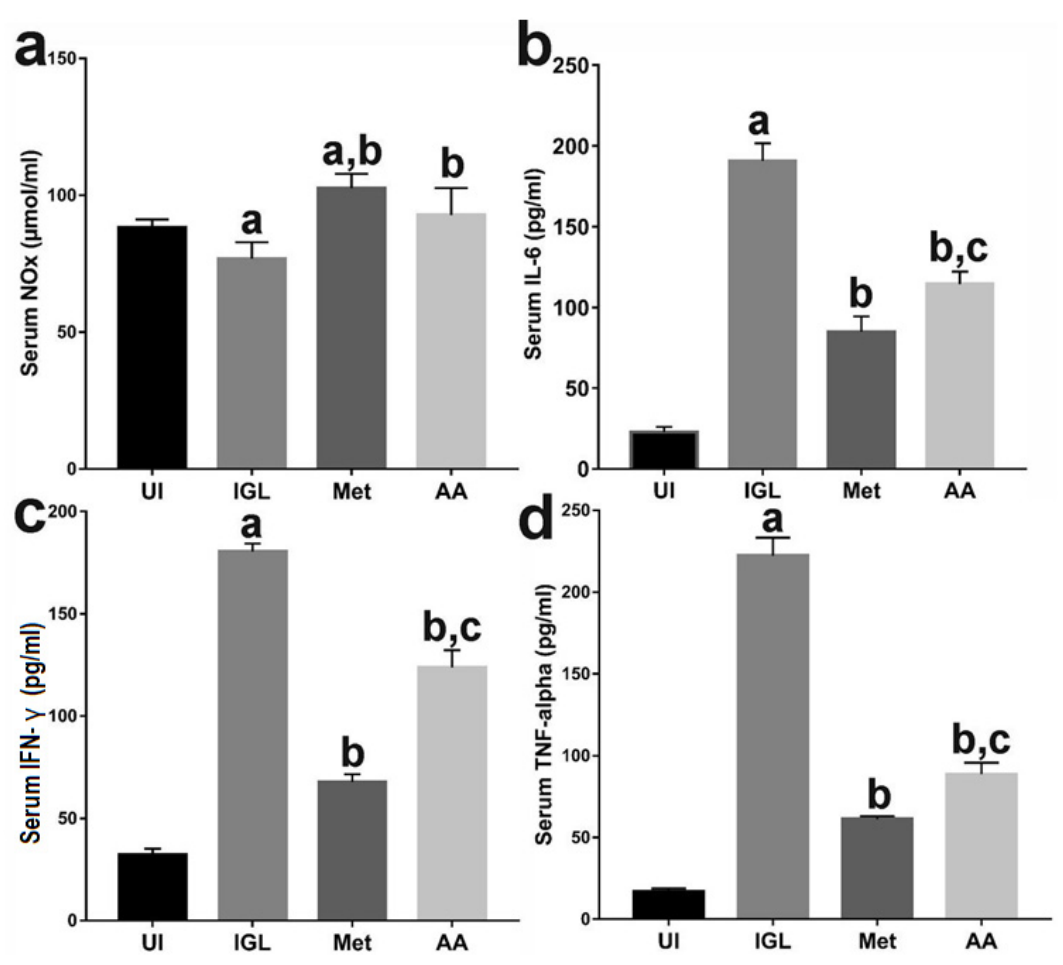

Figure 2. The effect of $A$. annua treatment on NO and proinflammatory cytokine levels in hamsters infected with G. lamblia. We measured NO end products (NOx) in serum of different groups (a) ("a" indicates a significant difference versus UI group $(p<0.001)$, while " $\mathrm{b}$ " indicates a significant difference versus IGL $(p<0.001))$. Serum levels of IL-6 (b), IFN- $\gamma(\mathbf{c})$, and TNF- $\alpha(\mathbf{d})$ were also quantified ("a" indicates a significant difference versus UI group, " $b$ " indicates a significant difference versus IGL group, and " $c$ " indicates a significant difference versus Met group $(p<0.05))$. Values represent means $\pm S D(n=8)$, and data were analyzed using ANOVA with Bonferroni corrections as a post hoc test. UI = uninfected animal group, while IGL = infected and untreated animals. Met = infected animals treated with metronidazole and $\mathrm{AA}=$ infected animals treated with $A$. annua extract.

\subsection{A. annua Treatment Restored Villi Structure of G. lamblia-Infected Animals}

To further explore the effects of metronidazole and A. annua treatments on giardiasisinduced small intestinal lesions, we stained sections taken from the proximal parts of the small intestine with hematoxylin and eosin (H\&E) stains. Small intestinal sections taken from UI animals showed normal intestinal villi and crypts (Figure 3a, arrowheads and arrows). The core of the villi is formed of connective tissue (Figure 3a, stars). In contrast, marked shortening and destruction of intestinal villi together with retraction of their connective tissue cores were observed in small intestinal sections taken from infected untreated animals (Figure $3 b$, arrowheads and stars). On the other hand, treating infected animals with metronidazole or A. annua restored the structure of the villi and their connective tissue cores (Figure $3 \mathrm{c}$,d; arrowheads and stars).

Next, we measured the villi length and found a significant reduction in the villi length in sections taken from IGL group animals compared to UI animals $(p<0.001)$ (Figure 4 ). However, treating infected animals with metronidazole (Met) or A. annua (AA) restored the normal villi length $(p<0.001)$. We did not find a significant difference between the villi length in Met and AA group. 


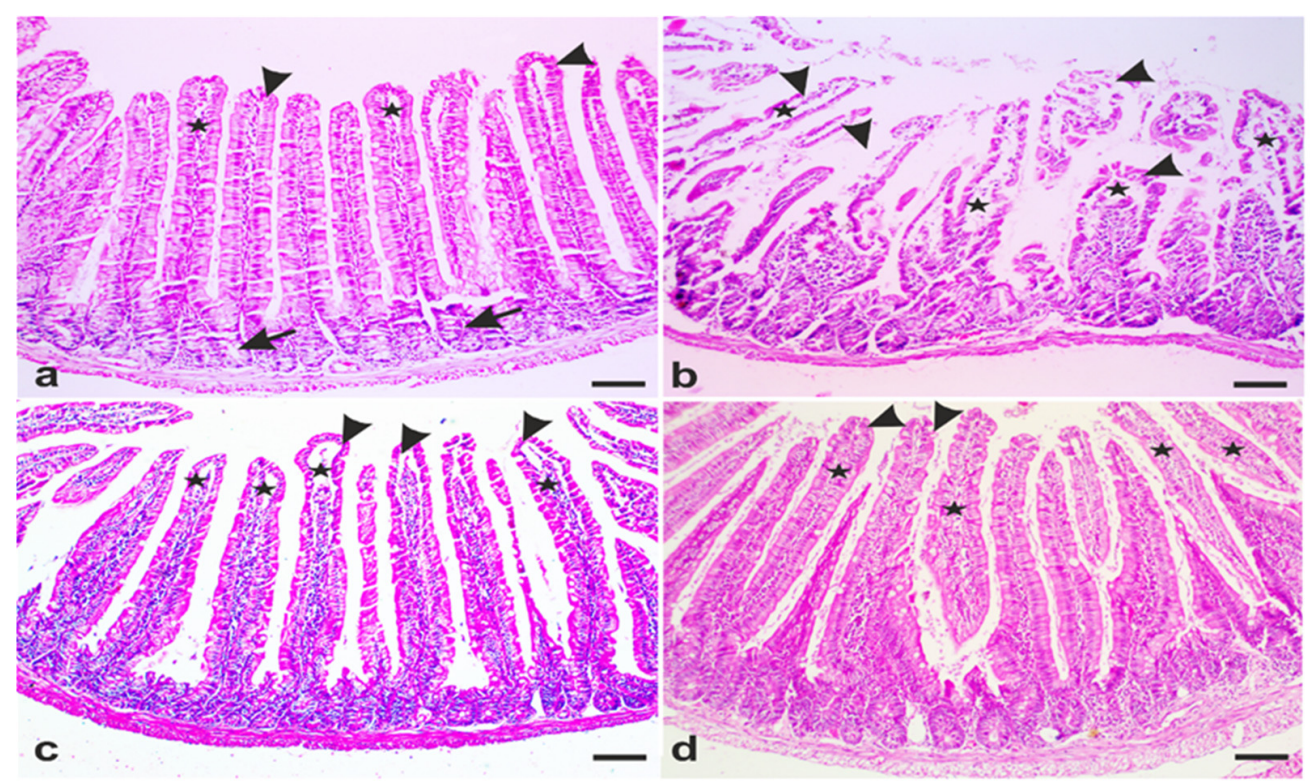

Figure 3. Representative photomicrographs of small intestinal sections from different groups of hamsters stained with hematoxylin and eosin. (a) Representative tissue from uninfected animals showing intact villi (arrowheads), crypts (arrows), connective core of the villi (stars). (b) Representative tissue from infected animals showing shortening and disruption of villi (arrowheads) and retraction of the connective tissue core of the villi (stars). (c) Representative tissue from infected animals that are treated with metronidazole with well-formed mucosal epithelial lining of the villi (arrowheads) and intact villi cores (stars). (d) Representative tissue from infected animals that are treated with A. annua extract showing well-formed villi (arrowheads) with regular epithelial lining and intact connective tissue core (stars). Scale bars $=100 \mu \mathrm{m}$.

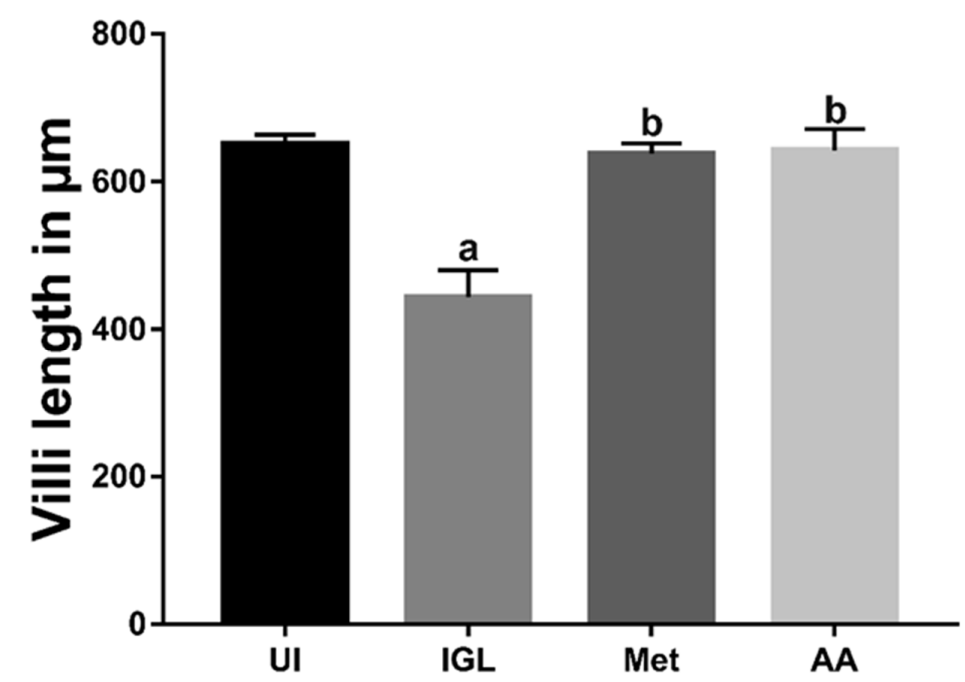

Figure 4. Treatment with $A$. annua preserved villi length in infected hamsters. $A$. annua extract treatment protected villi in infected hamsters. This effect was comparable to metronidazole treatment. "a" indicates significant difference versus UI group and " $\mathbf{b}$ " indicates significant difference versus IGL group $(p<0.001)$. Data are presented as means $\pm \mathrm{SD}(\mathrm{n}=3)$ and were analyzed using ANOVA test to compare the mean differences between groups with Bonferroni corrections as a post hoc test.

At higher magnification, small intestinal sections taken from uninfected hamsters exhibited normal histological structure of the villi with surface simple columnar epithelial cells (Figure 5a, arrowheads) and goblet cells (Figure 5a, asterisks). A few intraepithelial lymphocytes (IELs) were also observed (Figure 5a, arrows) and the core of the villi is formed 
of connective tissue (Figure 5a, stars). On the other hand, sections from infected animals showed desquamation of epithelial cells, disruption of the epithelium covering the villi (Figure 5b, double-headed arrows), increased IELs (Figure 5b, arrows), and disintegration of the connective tissue core of the villi with a few scattered connective tissue cells in this core (Figure 5b, stars). We also observed G. lamblia trophozoites in the intervillous spaces (Figure $5 b$, arrowheads). However, tissue sections of animals treated with metronidazole showed normal villi epithelium except for a few areas of epithelial disruptions (Figure 5c, double-headed arrow), regeneration of the connective tissue core of the villi (Figure $5 c$, stars), and decreased IEL infiltration (Figure 5c, arrows). Additionally, a few trophozoites were observed in the intervillous spaces (Figure $5 c$, arrowheads). Similar to metronidazoletreated group, A. annua treatment protected epithelial cells covering the villi, with only a few desquamated cells (Figure 5d, double-headed arrows), a few IELs (Figure 5d, arrows), and well-preserved villous connective tissue core (Figure $5 \mathrm{~d}$, stars). A few trophozoites were seen in the intervillous regions (Figure $5 d$, arrowheads).



Figure 5. Representative photomicrographs of small intestinal tissues of different groups of hamsters stained with hematoxylin and eosin. (a) Representative tissue from uninfected animals showing intact intestinal villi that are covered with simple columnar epithelium (arrowheads) with goblet cells (asterisks), villi core (stars), and a few IELs (arrows). (b) Representative tissue from infected untreated animals showing disruption of the mucosal epithelium (double-headed arrows), marked increase in IELs (arrows), retracted villi core with a few scattered connective tissue cells (stars), and presence of giardia trophozoites between villi (arrowheads). (c) Representative tissue from infected animals treated with metronidazole showing mucosal epithelium with a few desquamated cells (double-headed arrows), regeneration of the villi core (stars), a few IELs (arrows), and giardia trophozoites in the intervillous spaces (arrowheads). (d) Representative tissue from infected animals treated with A. annua showing preserved intestinal villi with a few desquamated cells (double-headed arrows) and intraepithelial lymphocytes (arrows). Stars point to intact villi core, whereas arrowheads point to a few giardia trophozoites found between the villi. Scale bar $=30 \mu \mathrm{m}$.

3.4. A. annua Treatment Reduced IEL Numbers in G. lamblia-Infected Animals, Restored the Goblet Cell Numbers, and Reversed Infection-Induced Pathological Effect on Muscularis Externa

Next, we counted the IELs/100 epithelial cells on images of H\&E-stained sections taken at 200× magnification according to previously published methods [57]. As shown in Figure 6, infected hamsters (IGL) had a significant increase in IEL numbers compared to uninfected (UI) animals $(p<0.001)$. However, treatment with metronidazole (Met) or A. annua (AA) significantly decreased the number of IELs in epithelial cells $(p<0.001)$. We did not find a significant difference between the effect of metronidazole and A. annua on the number of IELs. 


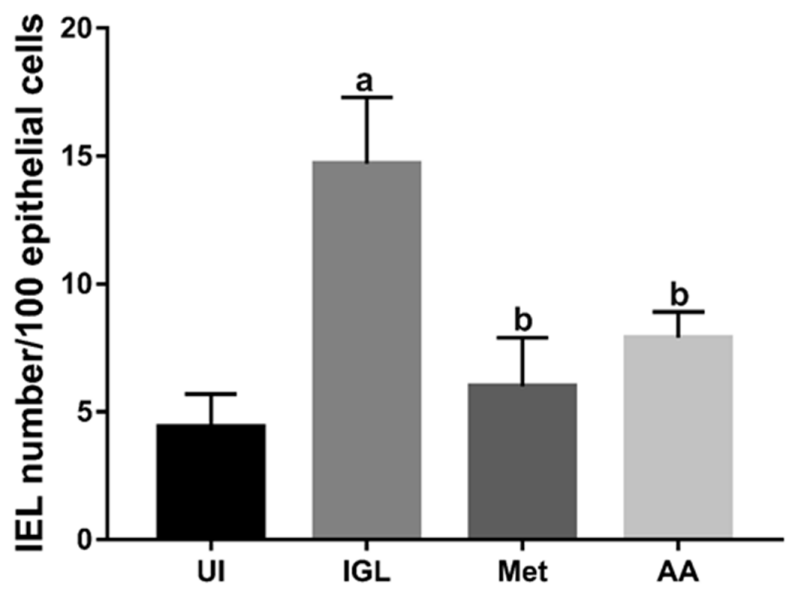

Figure 6. Treatment with A. annua reduced the number of intestinal IELs in infected hamsters. IELs were counted in images of intestinal tissues stained with hematoxylin and eosin. Infection of hamsters with G. lamblia significantly increased IEL count compared to uninfected animals (IGL versus UI). Treatment with $A$. annua significantly decreased IEL count compared to infected untreated animals (AA versus IGL). No significant difference was found between metronidazole or A. annua treatment (Met versus AA). "a" indicates significant difference versus UI group and " $\mathbf{b}$ " indicates significant difference versus IGL group $(p<0.001)$. Data are expressed as means $\pm \mathrm{SD}(\mathrm{n}=3)$ and were analyzed using ANOVA test with Bonferroni corrections as a post hoc test.

To examine whether A. annua treatment can restore goblet cell numbers, we stained our small intestinal sections with Periodic Acid Schiff reagent (PAS) and hematoxylin. In uninfected animals, goblet cells are distributed among the epithelial cells in the epithelium covering the villi (Figure 7a). A few goblet cells were observed in sections taken from infected untreated animals (Figure $7 \mathrm{~b}$ ). However, treating infected animals with metronidazole or A. annua reversed G. lamblia-induced reduction of goblet cells (Figure 7c,d).

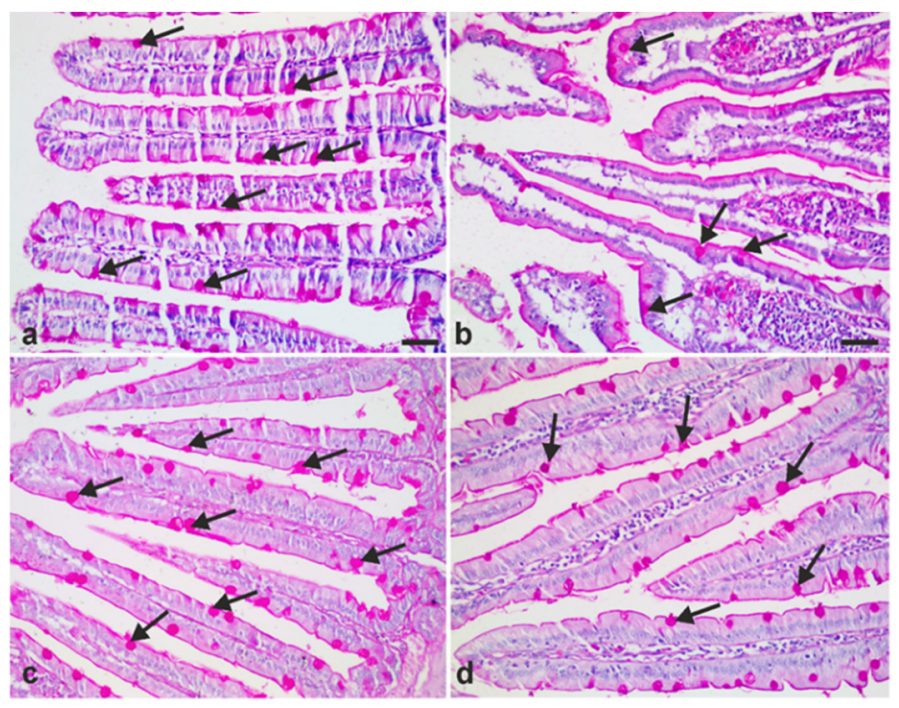

Figure 7. Representative photomicrographs of small intestinal tissues of different groups of hamsters stained with Periodic Acid Schiff (PAS) and hematoxylin to demonstrate goblet cells. (a) Representative tissue from uninfected animals showing intestinal villi with goblet cells scattered between epithelia cells. (b) Representative tissue from infected untreated animals showing depletion of goblet cells. (c) Representative tissue from infected animals treated with metronidazole showing restored goblet cells. (d) Representative tissue from infected animals treated with A. annua with restored goblet cells. Scale bar $=50 \mu \mathrm{m}$. 
To confirm our observations, we counted the number of goblet cells/100 epithelial cells in images of small intestinal sections stained with PAS and hematoxylin. A total of 2500 epithelial cells were counted according to previously published methods [59]. Infection of hamsters with Giardia lamblia (IGL group) significantly reduced goblet cell number compared to the uninfected (UI) animals (Figure 8) $(p<0.001)$. On the other hand, treating infected animals with metronidazole (Met) or A. annua (AA) significantly increased the goblet cell number compared to the infected untreated animals $(p<0.001)$. No significant difference was found between the effect of metronidazole and $A$. annua on goblet cell number.



Figure 8. Treatment with A. annua restored goblet cell numbers in small intestine of infected hamsters. Images of intestinal tissues stained with PAS and hematoxylin were used to count goblet cells. A. annua extract significantly increased the goblet cell number compared to infected untreated animals (AA versus IGL). A. annua effect was comparable to that of metronidazole. "a" indicates significant difference versus UI group and " $\mathbf{b}$ " indicates significant difference versus IGL group $(p<0.001)$. Data are means \pm SD $(n=3)$ and were analyzed using ANOVA test with Bonferroni corrections as a post hoc test.

Earlier, Pavanelli et al. have demonstrated that giardiasis reduced the muscularis externa thickness [19]. Therefore, we sought to investigate whether treatment of infected animals with either metronidazole or $A$. annua would reverse giardiasis-induced muscularis externa changes. In sections taken from the small intestine of uninfected hamsters, the muscularis externa is composed of smooth muscle fibers arranged in two layers, inner circular and outer longitudinal layers. These cells have acidophilic cytoplasm and elongated vesicular centrally located nuclei (Figure 9a). As expected, small intestinal sections taken from infected untreated hamsters showed extensive vacuolation of muscle cells of the muscularis externa (Figure 9b, arrows). Additionally, there was a reduction in the thickness of the muscularis externa of these animals. In contrast, small intestinal section of animals treated with metronidazole or $A$. annua showed decreased cytoplasmic vacuolation of smooth muscle cells (Figure 9c,d; arrows). Moreover, muscularis externa layers appeared thicker than those of infected untreated animals (Figure 9c,d).

To confirm our results, we measured the thickness of the muscularis externa, using Fiji ImageJ software version $1.52 \mathrm{p}$, in 15 pictures of random fields taken at $400 \times$ magnification. As shown in Figure 10, infection of hamsters with G. lamblia significantly reduced muscularis externa thickness compared to the uninfected animals $(p<0.001)$. On the other hand, treating infected animals with metronidazole (Met) or A. annua (AA) extract significantly increased the muscularis externa thickness compared to the infected untreated animals $(p<0.001)$. No significant difference was observed between the effects of the two treatments. 


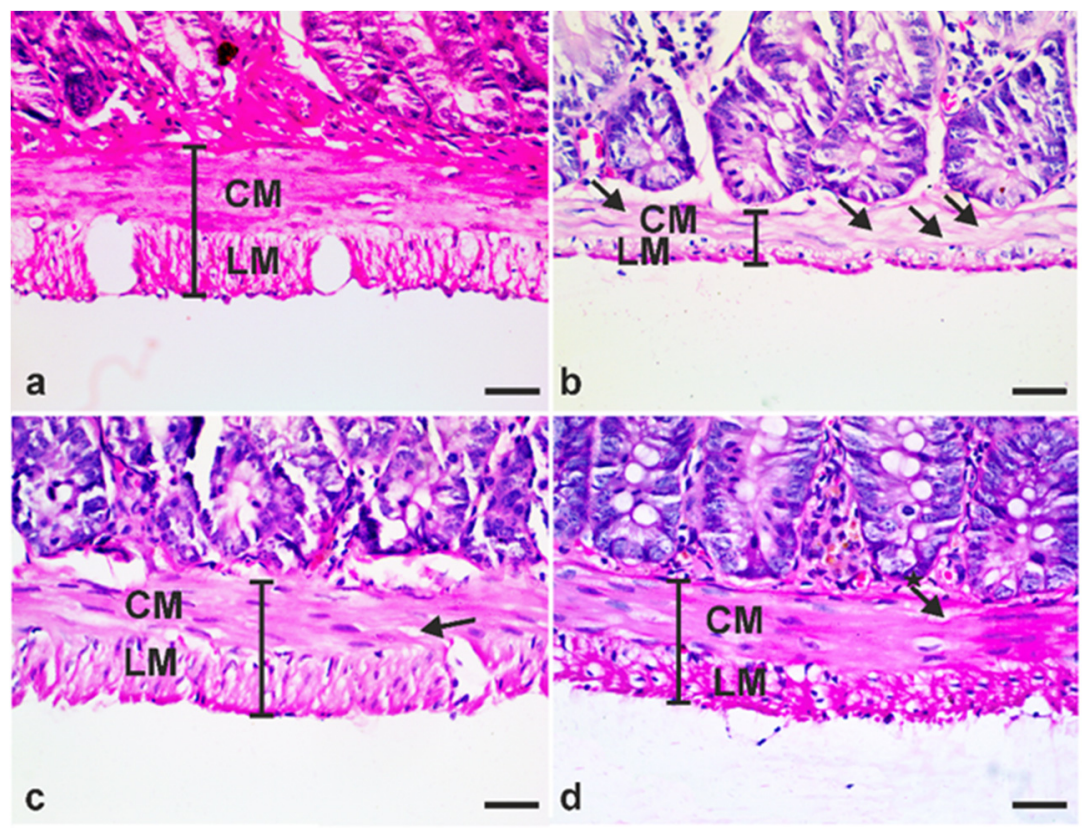

Figure 9. Treatment with A. annua restored pathological changes in muscularis externa due to $G$. lamblia infection. (a) Representative intestinal tissue from uninfected animals showing well-formed muscularis externa composed of smooth muscle fibers arranged in two layers; inner circular (CM) and outer longitudinal (LM) layers. (b) Representative intestinal tissue from infected untreated animals with extensively vacuolated muscle fibers (arrows) and decreased thickness of muscularis externa. (c) Representative intestinal tissue from infected animals treated with metronidazole with a few muscle fibers with vacuolation (arrows). (d) A representative tissue from small intestine of animals infected and treated with $A$. annua extract showing well-formed muscularis externa layers and a few fibers with vacuolation (arrows). In all panels, the vertical lines with brackets indicate the muscularis externa thickness. Scale bar $=30 \mu \mathrm{m}$.

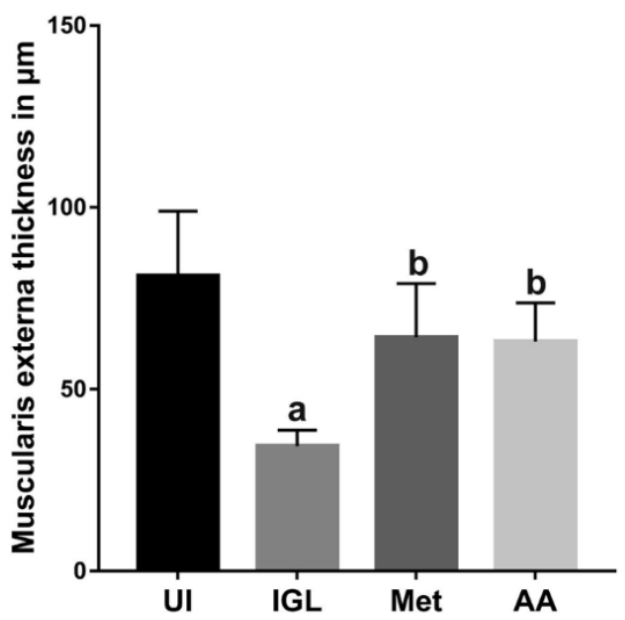

Figure 10. Treatment with A. annua reversed the pathological effect of G. lamblia infection on muscularis externa thickness. Infection of hamsters with G. lamblia (IGL) significantly decreased the muscularis externa thickness compared to uninfected animals (UI). Treatment of infected hamsters with $A$. annua extract (AA) significantly increased the muscularis externa thickness compared to infected untreated animals, an effect which was comparable to that after metronidazole treatment (Met). (a) indicates significant difference versus UI group. (b) indicates significant difference versus IGL group $(p<0.001)$. Data are expressed as means \pm SD $(n=3)$ and were analyzed using ANOVA test with Bonferroni corrections as a post hoc test. 


\subsection{A. annua Treatment Modulates iNOS Expression and Protects Intestinal Cells from Apoptosis}

A large body of evidence has shown that inducible nitric oxide synthase (iNOS) is highly expressed following G. lamblia infection and that NO is important for elimination of the parasite $[29,60]$. To investigate whether treating infected hamsters with metronidazole or A. апnиa would modulate the expression of iNOS, we employed immunohistochemistry to examine iNOS expression in tissue from the small intestine. In uninfected animals, we showed that iNOS is expressed in connective tissue cells in the core of the villi (Figure 11a, arrows) and barely in the enterocytes (Figure 11a, arrowheads). Infection of hamsters with G. lamblia induced intense iNOS signals in enterocytes covering the villi (Figure 11b, arrows). In infected animals that are treated with metronidazole, moderate iNOS expression was observed in villicore connective tissue cells (Figure 11c, arrows) and enterocytes (Figure 11c, arrowheads). In contrast, small intestinal tissues from $A$. annua-treated animals showed a few cells of the villi core expressing iNOS (Figure 11d, arrows) and weak iNOS signals in enterocytes (Figure 11d, arrowheads).



Figure 11. A. annua treatment of infected hamsters modulated iNOS expression in small intestine. (a) iNOS expression was localized in core intestinal cells of infected untreated animals (arrows) with no iNOS immunoreactivity in enterocytes. (b) Enterocytes showed high expression of iNOS in infected untreated animals (arrowheads). (c) Moderate iNOS expression was detected in core cells (arrows) as well as enterocytes (arrowheads) of intestines taken from infected animals that were treated with metronidazole. (d) Low iNOS expression was detected in villi core mononuclear cells of infected animals that were treated with A. annua extract (arrows) and was barely detected in enterocytes (arrowheads). Scale bar $=30 \mu \mathrm{m}$.

Previously, it has been demonstrated that G. lamblia trophozoites induce apoptosis in cultured enterocytes [18]. Therefore, we sought to test whether treating infected hamsters with $A$. annua extract would attenuate giardia-induced apoptosis in small intestine. We immunostained our small intestinal sections with anti-caspase- 3 antibodies. In uninfected control animals, weak caspase- 3 signals were observed in the enterocytes, lamina propria cells (Figure 12a, arrows), crypt cells, and muscularis externa layers (Figure 12b, arrows). In contrast, high levels of caspase-3 were detected in small intestinal epithelial cells and lamina propria cells (Figure 12c, arrows) of infected untreated animals. We also observed strong caspase-3 signals in cells lining the crypts as well as smooth muscle cells of muscularis 
externa layers (Figure 12d, arrows). Metronidazole-treated animals had fewer caspase-3positive villi epithelial cells, crypt cells, and muscularis externa cells (Figure 12e,f; arrows). Interestingly, caspase- 3 was significantly lower in intestine of A. annua-treated animals compared to infected untreated animals and metronidazole-treated animals (Figure 12g, h; arrows). The previous results show that $A$. annua treatment modulates iNOS expression and protects intestinal tissue from apoptotic cell death due to infection with G. lamblia.



Figure 12. Treatment with A. annua inhibited apoptosis of intestinal cells that is induced by G. lamblia infection. (a,b) Representative intestinal tissue sections of small intestine, from uninfected hamsters, showing weak caspase-3 signals (arrows). (c) Representative intestinal tissue, from infected animals, showing strong caspase-3 signals in enterocytes and lamina propria cells (arrows) and in (d) crypts and muscularis externa (arrows). Representative intestinal tissue, from infected animals treated with metronidazole, showing lower levels of caspase- 3 in the enterocytes and villi core cells (e) (arrows) and in crypt cells and muscularis externa (f). (g,h) showing a very low level of caspase-3 in intestinal tissue of infected animals that are treated with A. annua. Scale bar $=30 \mu \mathrm{m}$.

\section{Discussion}

Giardiasis is a major worldwide health problem that is caused by G. lamblia parasite. Studies have reported resistance of this parasite to commonly used drugs [33,34]. However, many research groups have identified the use of plants and plant-derived products, including A. annua, for the treatment of parasitic diseases [61-63]. Accordingly, in the current study, we used a hamster model of giardiasis to assess the efficacy of ethanolic extract of $A$. annua in giardiasis. We show for the first time that $A$. annua ethanolic extract significantly reduces G. lamblia trophozoite counts in small intestine of hamsters. Additionally, we show that $A$. annua restored G. lamblia-induced reduction of nitric oxide and significantly lowered IL-6, IFN- $\gamma$, and TNF- $\alpha$ production due to G. lamblia infection. Furthermore, A. annua extract reversed G. lamblia-induced pathological changes in villi heights, IEL numbers, goblet cell numbers, and muscularis externa thickness. Our results suggest an anti-giardia therapeutic effect of $A$. annua ethanolic extract.

In the present study, G. lamblia-infected hamsters treated with $A$. annua extract showed a marked reduction in the number of trophozoites in intestinal tissues in comparison with the infected untreated animals. This finding is in line with Alin and Bjorkman's study which showed that artemisinin, an A. annua active ingredient, inhibited the growth of malaria parasite in a concentration-dependent manner [64]. Additionally, in vitro studies demonstrated that $A$. аnпиа extract killed giardia trophozoites and this effect was concentration- and time-dependent [47]. We believe that reduction of G. lamblia trophozoite counts in our study after $A$. annua treatment could be through direct killing or growth inhibition of the trophozoites.

Several studies have suggested that NO plays an important role in the elimination of G. lamblia trophozoites [24,65]. To survive in the intestine, G. lamblia trophozoites limit host production of NO by competing with the host for arginine, as they use it as an energy source during various stages of growth [27]. Additionally, in vitro experiments 
have demonstrated that G. lamblia trophozoites secrete arginase, which breaks down arginine [66]. Furthermore, Maloney et al. reported an increased production of arginases by small intestinal macrophages during giardiasis [28]. In line with these data, we have shown reduction in serum NO end products (NOx) levels in animals infected with G. lamblia. Although we, in the current work, and others have reported increased expression of iNOS in the intestine of infected animals, this failed to increase NO levels due to arginine deficiency $[29,60]$. However, we have shown that treatment with $A$. annua extract increased NO production (as evidenced by increased serum NOx). This could be attributed to either the inhibitory effect of A. annua on G. lamblia trophozoite growth or inhibition of arginase release by macrophages. This assumption is partially supported by the work of Yang and colleagues who showed that $A$. апnи derivatives inhibited activation of macrophages in vitro [67]. However, the increased NO levels in our study, after $A$. annua treatment, were associated with decreased expression of iNOS. The increased NO production in $A$. annua-treated animals could be explained by Li etal.'s study. This study demonstrated that neuronal nitric oxide synthase (nNOS) plays a more significant role in giardiasis than iNOS [68]. Therefore, A. annua could increase NO levels through increased expression of nNOS rather than iNOS. However, this speculation needs further investigation.

Our results also showed significant increase in proinflammatory cytokines, namely; IL-6, TNF- $\alpha$, and IFN- $\gamma$ in animals infected with G. lamblia. Our findings are in line with previous reports that demonstrated increased cytokine production in TLR2-deficient mice which led to reduction in parasite burden and alleviated giardiasis [69-71]. Additionally, Bienz et al. showed that IL-6 deficient mice failed to control G. lamblia infection [21]. Moreover, mice deficient in TNF- $\alpha$ have an increased parasite load and prolonged G. lamblia infection [69]. However, increased production of inflammatory cytokines during $G$. lamblia infection was associated with pathological changes in the small intestine [72]. In our study, treatment with $A$. annua reduced serum IL-6 levels, TNF- $\alpha$, and IFN- $\gamma$ compared to those of infected untreated animals. However, these levels were higher than those of metronidazole-treated animals. Therefore, we believe that treatment with $A$. annua would be advantageous over metronidazole since IL-6 blocks epithelial cells apoptosis and helps in epithelial repair [73,74].

Our histological analyses show that infection of hamsters with G. lamblia led to shortening of the intestinal villi, shedding, and desquamation of enterocytes. These effects could be due to the secreted parasite proteins with proteolytic activities. These proteins could lead to disruption of cell-cell junctions and enterocyte damage in vitro [75]. Additionally, Scott and colleagues have demonstrated that intraepithelial $\mathrm{CD} 8^{+} \mathrm{T}$ cells destroyed the apical membrane of enterocytes, with loss of brush border and reduced disaccharidases activities [76]. Other experiments have reported that treating small intestinal epithelial cells with IFN- $\gamma$ disrupts mucosal barrier function through loss of zonula occludens (ZO)-1 and increased epithelial permeability [77]. Moreover, Troeger et al. as well as Fisher et al. have associated enterocyte damage with giardia-induced apoptosis $[78,79]$. Furthermore, several authors have suggested that TNF- $\alpha$ signaling through TNF- $\alpha$ receptor 1 (TNFR1) induced enterocytes apoptosis in a caspase-dependent manner [80-82]. In line with this hypothesis, our immunohistochemical data show that G. lamblia infection increased caspase-3 levels, which could account for tissue damage seen in our model. Taken together, small intestinal damage observed in our model could be due to the parasite secretory products and/or because of elevated cytokine levels.

However, treating infected animals with $A$. annua extract markedly decreased desquamated enterocytes with nearly normal villi covering. This effect could be attributable to the direct toxic effect of $A$. annua on G. lamblia which could protect enterocytes from the proteolytic enzymes secreted by the parasite. This assumption is partially supported by the work of Jiao and colleagues who demonstrated that $A$. annua leaf extract killed Eimeria tenella, an intracellular parasite that infects chicken enterocytes [46]. In the same study, the authors also demonstrated that $A$. аnnua decreased the expression of the inflammatory markers; nuclear factor-kappa B(NF-kB) and IL-17. Moreover, Sun et al. showed that 
artesunate, an A. annua ingredient, induced apoptosis of lamina propria macrophages and dendritic cells and decreased mucosal expression of TNF- $\alpha$ in a rodent model of colitis [83]. Numerous studies have associated NF-kB and TNF- $\alpha$ with various inflammatory conditions $[84,85]$. Therefore, controlling the activation of NF-kB and expression of TNF- $\alpha$ could account for the curative effect of $A$. апnиа. Treating infected animals with $A$. annua extract also decreased serum IFN- $\gamma$ levels. This effect of $A$. annua could account for alleviation of morphological changes that occurs during G. lamblia infection. On the other hand, Jiao et al. have demonstrated that $A$. аnnua leaves induced apoptosis of Eimeria tenella-infected enterocytes [46]. Lang and colleagues have also reported that $A$. annua inhibited the viability of resistant cancer cells [86]. In the same context, our immunohistochemistry data revealed that treating infected animals with $A$. annua extract reduced the amount of caspase-3 in enterocytes. In line with this finding, Yuan et al. demonstrated that Artemisia derivatives protected mice liver against the injurious effect of acetaminophen through decreased cellular levels of caspase-3 and -8 in addition to lower serum TNF- $\alpha$ levels [87].Therefore, A. annua components could inhibit growth or induce apoptosis of infected/stressed cells as suggested by Deng et al. and Jiao et al. reports $[46,88]$, whereas healthy cells could be protected by A. апnua derivatives as shown by us and others [87]. Altogether, A. annua attenuated giardia-induced enterocytes damage through direct toxic effect on G. lamblia, anti-inflammatory and possible anti-apoptotic effect. However, these mechanisms of $A$. апnиa therapeutic effect need further investigation.

In the current study, intestinal sections of infected untreated animals showed increased IEL numbers, which is in line with a previous report [76]. IELs are part of the immune mechanism to clear G. lamblia infection [89]. This rise of IEL numbers could be a response to antigens secreted by the parasite [90]. Unlike immunocompetent animals, nude athymic mice failed to eliminate Giardia infection, suggesting a role for $\mathrm{T}$ cells in elimination of the parasite [90]. Both $\mathrm{CD}^{+}$and $\mathrm{CD} 8^{+}$cells contribute to increased IELs during giardiasis [76]. However, increased IELs have been implicated in villus damage and epithelial injury during giardiasis. Scott and colleagues have demonstrated that transplantation of activated $\mathrm{CD}^{+} \mathrm{T}$ cell from Giardia-infected animals to normal mice was associated with epithelial tissue damage [76]. Additionally, Ebert demonstrated that G. lamblia increased proliferation of $\mathrm{CD}^{+} \mathrm{T}$ cells and increased secretion of IFN- $\gamma$ from both intestinal and blood lymphocytes [90]. On the contrary, animals treated with A. annua showed lower number of IELs compared to infected untreated animals. This observation could be attributed to the reduction of the parasite load in treated animals.

Goblet cells are essential for protection of the intestinal epithelium from luminal pathogens by secreting mucins which form a protective viscous barrier against invading pathogens [91,92]. In giardiasis, trophozoites colonize the intestine by secreting proteases which disrupt the mucus barrier [93]. Interestingly, Shukla and Sidhu have shown that infection of mice with G. lamblia reduced goblet cell numbers, increased excretion of cysts in stool, and decreased trophozoite count in the intestine [94]. Similarly, we show that infection of animals with G. lamblia significantly reduced goblet cell number compared to uninfected animals. This reduction in the number of goblet cells could be due to the breakdown of mucin by trophozoites' proteases [93], and hence could not be detected by Periodic Acid Schiff (PAS) reagent.

In our study, we showed that treating infected hamsters with $A$. annua led to restoration of goblet cell number. This could be attributable to the direct cytotoxic effect of $A$. annua on trophozoites as we mentioned earlier. Therefore, we can also assume that increased goblet cell number and hence mucus production by A. annua impaired colonization of the intestine by giardia trophozoites. This assumption is supported by the in vitro experiments of Roskens and Erlandsen who demonstrated that mucin inhibited the attachment of trophozoite to the substratum [95].

A possible limitation of our study should be noted here. We used a high dose of A. annua ethanolic extract similar to a number of studies [96,97]. Using a high dose of $A$. апnиa ethanolic extract ensures sufficient concentration of all active ingredients, 
particularly polysaccharides, coumarins, saponins, phytosterols, essential oils, polyphenols, and flavonoids [98]. This is supported by the finding that the use of the whole plant is more effective in the treatment of a rodent malaria model, as compared to the use of a comparable dose of pure artemisinin [99].

In conclusion, infection of hamsters with G. lamblia lowered NO production, while increasing IL-6, IFN- $\gamma$, and TNF- $\alpha$. Additionally, G. lamblia infection reduced villus height, goblet cell number, and muscularis externa thickness, while increasing IEL numbers. Interestingly, treatment with $A$. annua reduced inflammation and pathological damage to the intestine and the therapeutic effect was comparable to that of metronidazole. Treatment of infected animals with $A$. annua extract also reduced small intestinal trophozoite count. Therefore, we believe that $A$. апnи extract could be a potential therapeutic option for giardiasis.

\section{Conclusions}

The increase in resistance of G. lamblia to commonly used anti-giardia agents necessitates the development of novel therapeutics. In this study, we show that A. annua extract is effective in controlling giardiasis in a hamster disease model. Furthermore, we demonstrate that the $A$. annua exerts its therapeutic effect by reducing trophozoite count, alleviating inflammation, and reversing pathological damage to the intestinal wall. Therefore, we believe that $A$. аnпиa could be a potential effective therapeutic for the management of $G$. lamblia resistant strains.

Author Contributions: Conceptualization, T.H.A.-E. and A.M.E.-K.; methodology, T.H.A.-E., I.A.M.A.R., S.S.F., O.H.A., and A.M.E.-K.; software (Fiji ImageJ software, version 1.52p), T.H.A.-E. and A.M.E.-K.; writing—original drafts, T.H.A.-E., and A.M.E.-K.; formal analysis, T.H.A.-E., K.S.A., A.A., H.A.E., and A.M.E.-K.; writing-review and editing, I.A.M.A.-R., A.R.M., S.S.F., O.H.A., K.S.A., A.A., and H.A.E.; visualization, T.H.A.-E., I.A.M.A.-R., S.S.F., and O.H.A.; investigation, A.R.M., H.A.E., and A.M.E.-K.; data collection, A.R.M.; supervision, H.A.E.; project administration, H.A.E. and A.M.E.-K.; critical revisions and writing, H.A.E. All authors have read and agreed to the published version of the manuscript.

Funding: This research received no external funding.

Institutional Review Board Statement: The study was conducted according to the guidelines of the Declaration of Helsinki, and approved by the Research and Ethics Committee of the Faculty of Medicine, South Valley University (protocol code SVU-MED-PAR008-4).

Informed Consent Statement: Not applicable.

Data Availability Statement: Not applicable.

Conflicts of Interest: The authors declare no conflict of interest.

\section{List of Abbreviations}

$\begin{array}{ll}\text { A. annua } & \text { Artemisia annua } \\ \text { HPF } & \text { High power field } \\ \text { IEL } & \text { Intraepithelial Lymphocytes } \\ \text { IL-6 } & \text { Interlukin-6 } \\ \text { IFN- } \gamma & \text { Interferon- } \gamma \\ \text { iNOS } & \text { Inducible nitric oxide synthase } \\ \text { NF-kB } & \text { Nuclear factor-kappa B } \\ \text { nNOS } & \text { Neuronal nitric oxide synthase } \\ \text { NO } & \text { Nitric oxide } \\ \text { PAS } & \text { Periodic Acid Schiff reagent } \\ \text { TNF- } \alpha & \text { Tumor necrosis factor- } \alpha \\ \text { TNFR1 } & \text { TNF- } \alpha \text { receptor } 1\end{array}$




\section{References}

1. Gardner, T.B.; Hill, D.R. Treatment of giardiasis. Clin. Microbiol. Rev. 2001, 14, 114-128. [CrossRef] [PubMed]

2. Adam, R.D. Biology of Giardia lamblia. Clin. Microbiol. Rev. 2001, 14, 447-475. [CrossRef] [PubMed]

3. Ankarklev, J.; Jerlstrom-Hultqvist, J.; Ringqvist, E.; Troell, K.; Svard, S.G. Behind the smile: Cell biology and disease mechanisms of Giardia species. Nat. Rev. Microbiol. 2010, 8, 413-422. [CrossRef]

4. Thompson, R.C. Giardiasis as a re-emerging infectious disease and its zoonotic potential. Int. J. Parasitol. 2000, 30, 1259-1267. [CrossRef]

5. Foronda, P.; Bargues, M.D.; Abreu-Acosta, N.; Periago, M.V.; Valero, M.A.; Valladares, B.; Mas-Coma, S. Identification of genotypes of Giardia intestinalis of human isolates in Egypt. Parasitol. Res. 2008, 103, 1177-1181. [CrossRef] [PubMed]

6. El-Naggar, S.M.; El-Bahy, M.M.; Abd Elaziz, J.; El-Dardiry, M.A. Detection of protozoal parasites in the stools of diarrhoeic patients using different techniques. J. Egypt Soc. Parasitol. 2006, 36, 7-22.

7. Baiomy, A.M.; Mohamed, K.A.; Ghannam, M.A.; Shahat, S.A.; Al-Saadawy, A.S. Opportunistic parasitic infections among immunocompromised Egyptian patients. J. Egypt Soc. Parasitol. 2010, 40, 797-808.

8. Abdel-Hafeez, E.H.; Ahmad, A.K.; Ali, B.A.; Moslam, F.A. Opportunistic parasites among immunosuppressed children in Minia District, Egypt. Korean J. Parasitol. 2012, 50, 57-62. [CrossRef]

9. Feng, Y.; Xiao, L. Zoonotic potential and molecular epidemiology of Giardia species and giardiasis. Clin. Microbiol. Rev. 2011, 24, 110-140. [CrossRef]

10. Eppig, C.; Fincher, C.L.; Thornhill, R. Parasite prevalence and the worldwide distribution of cognitive ability. Proc. Biol. Sci. 2010, 277, 3801-3808. [CrossRef]

11. Balcioglu, I.C.; Limoncu, E.; Ertan, P.; Yereli, K.; Ozbilgin, A.; Onag, A. Incidence of giardiasis among siblings in Turkey. Pediatr. Int. 2003, 45, 311-313. [CrossRef]

12. Veenemans, J.; Mank, T.; Ottenhof, M.; Baidjoe, A.; Mbugi, E.V.; Demir, A.Y.; Wielders, J.P.; Savelkoul, H.F.; Verhoef, H. Protection against diarrhea associated with Giardia intestinalis Is lost with multi-nutrient supplementation: A study in Tanzanian children. PLoS Negl. Trop. Dis. 2011, 5, e1158. [CrossRef]

13. Gonçalves, A.C.M.; Gabbay, Y.B.; Mascarenhas, J.D.; Yassaka, M.B.; Moran, L.C.; Fraga, V.D.; Castro, E.; Franco, C.; Machado, R.L.D.; Rossit, A.R.B. Calicivirus and Giardia lamblia are associated with diarrhea in human immunodeficiency virus-seropositive patients from southeast Brazil. Am. J. Trop. Med. Hyg. 2009, 81, 463-466. [CrossRef] [PubMed]

14. Reynoso, R.; Ponce, M.; Rosas, L.E.; Ramos, A.; Mart, M.N.; Gonz, A. The invasive potential of Giardia intestinalis in an in vivo model. Sci. Rep. 2015, 16, 1-8. [CrossRef]

15. Panarelli, N.C.; Gobara, N.; Hoda, R.S.; Chaump, M.; Jessurun, J.; Yantiss, R.K. Cytology Preparations of Formalin Fixative Aid Detection of Giardia in Duodenal Biopsy Samples. Am. J. Surg. Pathol. 2017, 41, 570-574. [CrossRef] [PubMed]

16. Ventura, L.L.; Oliveira, D.R.; Viana, J.C.; Santos, J.F.; Caliari, M.V.; Gomes, M.A. Impact of protein malnutrition on histological parameters of experimentally infected animals with Giardia lamblia. Exp. Parasitol. 2013, 133, 391-395. [CrossRef]

17. Panaro, M.A.; Cianciulli, A.; Mitolo, V.; Mitolo, C.I.; Acquafredda, A.; Brandonisio, O.; Cavallo, P. Caspase-dependent apoptosis of the HCT-8 epithelial cell line induced by the parasite Giardia intestinalis. FEMS Immunol. Med. Microbiol. 2007, 51, 302-309. [CrossRef] [PubMed]

18. Chin, A.C.; Teoh, D.A.; Scott, K.G.-E.; Meddings, J.B.; Macnaughton, W.K.; Buret, A.G. Strain-dependent induction of enterocyte apoptosis by Giardia lamblia disrupts epithelial barrier function in a caspase-3-dependent manner. Infect. Immun. 2002, 70, 3673-3680. [CrossRef]

19. Pavanelli, M.F.; Colli, C.M.; Bezagio, R.C.; Gois, M.B.; de Melo, G.d.A.N.; de Almeida Araujo, E.J.; Sant'Ana, D.d.M.G. Assemblages A and B of Giardia duodenalis reduce enteric glial cells in the small intestine in mice. Parasitol. Res. 2018, 117, 2025-2033. [CrossRef]

20. Zhou, P.; Li, E.; Zhu, N.; Robertson, J.; Nash, T.; Singer, S.M. Role of interleukin-6 in the control of acute and chronic Giardia lamblia infections in mice. Infect. Immun. 2003, 71, 1566-1568. [CrossRef]

21. Bienz, M.; Dai, W.J.; Welle, M.; Gottstein, B.; Müller, N. Interleukin-6-deficient mice are highly susceptible to Giardia lamblia infection but exhibit normal intestinal immunoglobulin A responses against the parasite. Infect. Immun. 2003, 71, 1569-1573. [CrossRef] [PubMed]

22. Lee, H.Y.; Kim, J.; Noh, H.J.; Kim, H.P.; Park, S.J. Giardia lamblia binding immunoglobulin protein triggers maturation of dendritic cells via activation of TLR4-MyD88-p38 and ERK1/2 MAPKs. Parasite Immunol. 2014, 36, 627-646. [CrossRef] [PubMed]

23. Kamda, J.D.; Nash, T.E.; Singer, S.M. Giardia duodenalis: Dendritic cell defects in IL-6 deficient mice contribute to susceptibility to intestinal infection. Exp. Parasitol. 2012, 130, 288-291. [CrossRef]

24. Eckmann, L.; Laurent, F.; Langford, T.D.; Hetsko, M.L.; Smith, J.R.; Kagnoff, M.F.; Gillin, F.D. Nitric oxide production by human intestinal epithelial cells and competition for arginine as potential determinants of host defense against the lumen-dwelling pathogen Giardia lamblia. J. Immunol. 2000, 164, 1478-1487. [CrossRef] [PubMed]

25. Popovic, P.J.; Zeh, H.J., 3rd; Ochoa, J.B. Arginine and immunity. J. Nutr. 2007, 137, 1681S-1686S. [CrossRef]

26. Das, P.; Lahiri, A.; Lahiri, A.; Chakravortty, D. Modulation of the arginase pathway in the context of microbial pathogenesis: A metabolic enzyme moonlighting as an immune modulator. PLoS Pathog. 2010, 6, e1000899. [CrossRef]

27. Brown, D.M.; Upcroft, J.A.; Edwards, M.R.; Upcroft, P. Anaerobic bacterial metabolism in the ancient eukaryote Giardia duodenalis. Int. J. Parasitol. 1998, 28, 149-164. [CrossRef] 
28. Maloney, J.; Keselman, A.; Li, E.; Singer, S.M. Macrophages expressing arginase 1 and nitric oxide synthase 2 accumulate in the small intestine during Giardia lamblia infection. Microbes Infect. 2015, 17, 462-467. [CrossRef]

29. Stadelmann, B.; Hanevik, K.; Andersson, M.K.; Bruserud, O.; Svärd, S.G. The role of arginine and arginine-metabolizing enzymes during Giardia-host cell interactions in vitro. BMC Microbiol. 2013, 13, 256. [CrossRef]

30. Dupouy-Camet, J. New drugs for the treatment of human parasitic protozoa. Parassitologia 2004, 46, 81-84.

31. Lalle, M. Giardiasis in the post genomic era: Treatment, drug resistance and novel therapeutic perspectives. Infect Disord. Drug Targets 2010, 10, 283-294. [CrossRef]

32. Huang, D.B.; White, A.C. An updated review on Cryptosporidium and Giardia. Gastroenterol. Clin. N. Am. 2006, 35, 291-314. [CrossRef]

33. Upcroft, J.A.; Dunn, L.A.; Wright, J.M.; Benakli, K.; Upcroft, P.; Vanelle, P. 5-Nitroimidazole drugs effective against metronidazoleresistant Trichomonas vaginalis and Giardia duodenalis. Antimicrob. Agents Chemother. 2006, 50, 344-347. [CrossRef]

34. Long, K.Z.; Rosado, J.L.; Montoya, Y.; de Lourdes Solano, M.; Hertzmark, E.; DuPont, H.L.; Santos, J.I. Effect of vitamin A and zinc supplementation on gastrointestinal parasitic infections among Mexican children. Pediatrics 2007, 120, e846-e855. [CrossRef] [PubMed]

35. Sofowora, A.; Ogunbodede, E.; Onayade, A. The role and place of medicinal plants in the strategies for disease prevention. Afr. J. Tradit. Complement. Altern. Med. 2013, 10, 210-229. [CrossRef]

36. Bora, K.S.; Sharma, A. The genus Artemisia: A comprehensive review. Pharm. Biol. 2011, 49, 101-109. [CrossRef]

37. Valderrábano, J.; Calvete, C.; Uriarte, J. Effect of feeding bioactive forages on infection and subsequent development of Haemonchus contortus in lamb faeces. Vet. Parasitol. 2010, 172, 89-94. [CrossRef] [PubMed]

38. Daddy, N.B.; Kalisya, L.M.; Bagire, P.G.; Watt, R.L.; Towler, M.J.; Weathers, P.J. Artemisia annua dried leaf tablets treated malaria resistant to ACT and i.v. artesunate: Case reports. Phytomedicine 2017, 32, 37-40. [CrossRef] [PubMed]

39. Ferreira, J.F.; Luthria, D.L.; Sasaki, T.; Heyerick, A. Flavonoids from Artemisia annua L. as antioxidants and their potential synergism with artemisinin against malaria and cancer. Molecules 2010, 15, 3135-3170. [CrossRef]

40. Chukwurah, P.N.; Brisibe, E.A.; Osuagwu, A.N.; Okoko, T. Protective capacity of Artemisia annua as a potent antioxidant remedy against free radical damage. Asian Pac. J. Trop. Biomed. 2014, 4, S92-S98. [CrossRef]

41. Mishina, Y.V.; Krishna, S.; Haynes, R.K.; Meade, J.C. Artemisinins inhibit Trypanosoma cruzi and Trypanosoma brucei rhodesiense in vitro growth. Antimicrob. Agents Chemother. 2007, 51, 1852-1854. [CrossRef] [PubMed]

42. Ferreira, J.F.; Peaden, P.; Keiser, J. In vitro trematocidal effects of crude alcoholic extracts of Artemisia annua, A. absinthium, Asimina triloba, and Fumaria officinalis: Trematocidal plant alcoholic extracts. Parasitol. Res. 2011, 109, 1585-1592. [CrossRef] [PubMed]

43. de Oliveira, T.C.; Silva, D.A.; Rostkowska, C.; Bela, S.R.; Ferro, E.A.; Magalhaes, P.M.; Mineo, J.R. Toxoplasma gondii: Effects of Artemisia annua L. on susceptibility to infection in experimental models in vitro and in vivo. Exp. Parasitol. 2009, 122, 233-241. [CrossRef] [PubMed]

44. Sen, R.; Bandyopadhyay, S.; Dutta, A.; Mandal, G.; Ganguly, S.; Saha, P.; Chatterjee, M. Artemisinin triggers induction of cell-cycle arrest and apoptosis in Leishmania donovani promastigotes. J. Med. Microbiol. 2007, 56, 1213-1218. [CrossRef] [PubMed]

45. Mesa, L.E.; Vasquez, D.; Lutgen, P.; Velez, I.D.; Restrepo, A.M.; Ortiz, I.; Robledo, S.M. In vitro and in vivo antileishmanial activity of Artemisia annua L. leaf powder and its potential usefulness in the treatment of uncomplicated cutaneous leishmaniasis in humans. Rev. Soc. Bras. Med. Trop. 2017, 50, 52-60. [CrossRef]

46. Jiao, J.; Yang, Y.; Liu, M.; Li, J.; Cui, Y.; Yin, S.; Tao, J. Artemisinin and Artemisia annua leaves alleviate Eimeria tenella infection by facilitating apoptosis of host cells and suppressing inflammatory response. Vet. Parasitol. 2018, 254, 172-177. [CrossRef]

47. Golami, S.; Rahimi-Esboei, B.; Mousavi, P.; Marhaba, Z.; Youssefi, M.R.; Rahimi, M.T. Survey on efficacy of chloroformic extract of Artemisia annua against Giardia lamblia trophozoite and cyst in vitro. J. Parasite Dis. 2016, 40, 88-92. [CrossRef]

48. Tariq, K.A.; Chishti, M.Z.; Ahmad, F.; Shawl, A.S. Anthelmintic activity of extracts of Artemisia absinthium against ovine nematodes. Vet. Parasitol. 2009, 160, 83-88. [CrossRef]

49. Dyab, A.K.; Yones, D.A.; Ibraheim, Z.Z.; Hassan, T.M. Anti-giardial therapeutic potential of dichloromethane extracts of Zingiber officinale and Curcuma longa in vitro and in vivo. Parasitol. Res. 2016, 115, 2637-2645. [CrossRef]

50. Aly, E.M.; Sabry, H.Y.; Fahmy, Z.H.; Zalat, R.S. Ef fi cacy of combination therapy (metronidazole and/or artemether) in experimental giardiasis and its impact on nonenzymatic oxidative stress biomarkers. Parasitol. United J. 2014, 68-74. [CrossRef]

51. Squires, J.M.; Ferreira, J.F.; Lindsay, D.S.; Zajac, A.M. Effects of artemisinin and Artemisia extracts on Haemonchus contortus in gerbils (Meriones unguiculatus). Vet. Parasitol. 2011, 175, 103-108. [CrossRef] [PubMed]

52. Laurence, D.R.; Bacharach, A.L. Evaluation of Drug Activities: Pharmacometrics; Academic Press: London, UK, 1964.

53. Fathy, F.M. Effect of mirazid (Commiphora molmol) on experimental giardiasis. J. Egypt Soc. Parasitol. 2011, 41, 155-177. [PubMed]

54. Rayan, P.; Stenzel, D.; McDonnell, P.A. The effects of saturated fatty acids on Giardia duodenalis trophozoites in vitro. Parasitol. Res. 2005, 97, 191-200. [CrossRef]

55. Nuttall, K.L.; Gordon, W.H.; Ash, K.O. Inductively coupled plasma mass spectrometry for trace element analysis in the clinical laboratory. Ann. Clin. Lab. Sci. 1995, 25, 264-271. [PubMed]

56. Drury, R.A.B.; Wallington, E.A.; Cameron, R. Carleton's Histological Technique (Oxford Medical Publications), 5th ed.; Oxford University Press: Oxford, UK, 1980. 
57. Chott, A.; Gerdes, D.; Spooner, A.; Mosberger, I.; Kummer, J.A.; Ebert, E.C.; Blumberg, R.S.; Balk, S.P. Intraepithelial lymphocytes in normal human intestine do not express proteins associated with cytolytic function. Am. J. Pathol. 1997, 151, 435-442. [PubMed]

58. Pacheco, F.T.F.; Carvalho, S.S.; Cardoso, L.S.; Andrade, L.S.; das Chagas, G.M.T.; Gomes, D.C.; Merces, C.F.; Rocha, F.C.; Silva, L.K.; Soares, N.M.; et al. Immune response markers in sera of children infected with Giardia duodenalis AI and AII subassemblages. Immunobiology 2019, 224, 595-603. [CrossRef] [PubMed]

59. Mello, R.d.O.; da Silva, C.M.G.; Fonte, F.P.; Silva, D.L.F.; Pereira, J.A.; Margarido, N.F.; Martinez, C.A.R. Evaluation of the number of goblet cells in crypts of the colonic mucosa with and without fecal transit. Rev. Col. Bras. Cir. 2012, 39, 139-145. [CrossRef]

60. Mokrzycka, M.; Kolasa, A.; Kosierkiewicz, A.; Wiszniewska, B. Inducible nitric oxide synthase in duodenum of children with Giardia lamblia infection. Folia Histochem. Cytobiol. 2010, 48, 191-196. [CrossRef]

61. Kim, W.S.; Choi, W.J.; Lee, S.; Kim, W.J.; Lee, D.C.; Sohn, U.D.; Shin, H.S.; Kim, W. Anti-inflammatory, Antioxidant and Antimicrobial Effects of Artemisinin Extracts from Artemisia annua L. Korean J. Physiol. Pharmacol. 2015, 19, 21-27. [CrossRef]

62. Calzada, F.; Yépez-Mulia, L.; Aguilar, A. In vitro susceptibility of Entamoeba histolytica and Giardia lamblia to plants used in Mexican traditional medicine for the treatment of gastrointestinal disorders. J. Ethnopharmacol. 2006, 108, 367-370. [CrossRef]

63. Rahimi-Esboei, B.; Ebrahimzadeh, M.A.; Gholami, S.; Falah-Omrani, V. Anti-giardial activity of Sambucus ebulus. Eur. Rev. Med. Pharmacol. Sci. 2013, 17, 2047-2050. [PubMed]

64. Alin, M.H.; Bjorkman, A. Concentration and time dependency of artemisinin efficacy against Plasmodium falciparum in vitro. Am. J. Trop. Med. Hyg. 1994, 50, 771-776. [CrossRef] [PubMed]

65. Fernandes, P.; Assreuy, J. Role of nitric oxide and superoxide in Giardia lamblia killing. Braz. J. Med. Biol. Res. 1997, 30, 93-99. [CrossRef]

66. Ringqvist, E.; Palm, J.E.; Skarin, H.; Hehl, A.B.; Weiland, M.; Davids, B.J.; Reiner, D.S.; Griffiths, W.J.; Eckmann, L.; Gillin, F.D.; et al. Release of metabolic enzymes by Giardia in response to interaction with intestinal epithelial cells. Mol. Biochem. Parasitol. 2008, 159, 85-91. [CrossRef]

67. Yang, Z.; Ding, J.; Yang, C.; Gao, Y.; Li, X.; Chen, X.; Peng, Y.; Fang, J.; Xiao, S. Immunomodulatory and anti-inflammatory properties of artesunate in experimental colitis. Curr. Med. Chem. 2012, 19, 4541-4551. [CrossRef] [PubMed]

68. Li, E.; Zhou, P.; Singer, S.M. Neuronal nitric oxide synthase is necessary for elimination of Giardia lamblia infections in mice. J. Immunol. 2006, 176, 516-521. [CrossRef]

69. Zhou, P.; Li, E.; Shea-Donohue, T.; Singer, S.M. Tumour necrosis factor alpha contributes to protection against Giardia lamblia infection in mice. Parasite Immunol. 2007, 29, 367-374. [CrossRef] [PubMed]

70. Matowicka-Karna, J.; Dymicka-Piekarska, V.; Kemona, H. IFN-gamma, IL-5, IL-6 and IgE in patients infected with Giardia intestinalis. Folia Histochem. Cytobiol. 2009, 47, 93-97. [CrossRef]

71. Li, X.; Zhang, X.; Gong, P.; Xia, F.; Li, L.; Yang, Z.; Li, J. TLR2(-/-) Mice Display Decreased Severity of Giardiasis via Enhanced Proinflammatory Cytokines Production Dependent on AKT Signal Pathway. Front. Immunol. 2017, 8, 1186. [CrossRef]

72. Solaymani-Mohammadi, S.; Singer, S.M. Host immunity and pathogen strain contribute to intestinal disaccharidase impairment following gut infection. J. Immunol. 2011, 187, 3769-3775. [CrossRef]

73. Kuhn, K.A.; Manieri, N.A.; Liu, T.-C.; Stappenbeck, T.S. IL-6 stimulates intestinal epithelial proliferation and repair after injury. PLoS ONE 2014, 9, e114195. [CrossRef]

74. Zong, X.; Hu, W.; Song, D.; Li, Z.; Du, H.; Lu, Z.; Wang, Y. Porcine lactoferrin-derived peptide LFP-20 protects intestinal barrier by maintaining tight junction complex and modulating inflammatory response. Biochem. Pharmacol. 2016, 104, 74-82. [CrossRef]

75. Cabrera-Licona, A.; Solano-Gonzalez, E.; Fonseca-Linan, R.; Bazan-Tejeda, M.L.; Raul, A.-G.; Bermudez-Cruz, R.M.; OrtegaPierres, G. Expression and secretion of the Giardia duodenalis variant surface protein 9B10A by transfected trophozoites causes damage to epithelial cell monolayers mediated by protease activity. Exp. Parasitol. 2017, 179, 49-64. [CrossRef]

76. Scott, K.G.; Yu, L.C.; Buret, A.G. Role of CD8+ and CD4+ T lymphocytes in jejunal mucosal injury during murine giardiasis. Infect. Immun. 2004, 72, 3536-3542. [CrossRef] [PubMed]

77. Youakim, A.; Ahdieh, M. Interferon-gamma decreases barrier function in T84 cells by reducing ZO-1 levels and disrupting apical actin. Am. J. Physiol. 1999, 276, G1279-G1288. [CrossRef]

78. Troeger, H.; Epple, H.J.; Schneider, T.; Wahnschaffe, U.; Ullrich, R.; Burchard, G.D.; Jelinek, T.; Zeitz, M.; Fromm, M.; Schulzke, J.D. Effect of chronic Giardia lamblia infection on epithelial transport and barrier function in human duodenum. Gut 2007, 56, 328-335. [CrossRef] [PubMed]

79. Cole, J.A.; Fisher, B.S.; Estran, C.E. Modeling Long-Term Host Cell-Giardia lamblia Interactions in an In Vitro Co-Culture System. PLoS ONE 2013, 8, e81104. [CrossRef]

80. Williams, J.M.; Duckworth, C.A.; Watson, A.J.; Frey, M.R.; Miguel, J.C.; Burkitt, M.D.; Sutton, R.; Hughes, K.R.; Hall, L.J.; Caamano, J.H.; et al. A mouse model of pathological small intestinal epithelial cell apoptosis and shedding induced by systemic administration of lipopolysaccharide. Dis. Model. Mech. 2013, 6, 1388-1399. [CrossRef] [PubMed]

81. Piguet, P.F.; Vesin, C.; Donati, Y.; Barazzone, C. TNF-induced enterocyte apoptosis and detachment in mice: Induction of caspases and prevention by a caspase inhibitor, ZVAD-fmk. Lab. Investig. 1999, 79, 495-500. [PubMed]

82. Parker, A.; Vaux, L.; Patterson, A.M.; Modasia, A.; Muraro, D.; Fletcher, A.G.; Byrne, H.M.; Maini, P.K.; Watson, A.J.M.; Pin, C. Elevated apoptosis impairs epithelial cell turnover and shortens villi in TNF-driven intestinal inflammation. Cell Death Dis. 2019, 10, 108. [CrossRef] [PubMed] 
83. Sun, W.; Han, X.; Wu, S.; Wu, J.; Yang, C.; Li, X. Unexpected mechanism of colitis amelioration by artesunate, a natural product from Artemisia annua L. Inflammopharmacology 2020, 28, 851-868. [CrossRef] [PubMed]

84. Ali, F.E.M.; Hassanein, E.H.M.; Bakr, A.G.; El-Shoura, E.A.M.; El-Gamal, D.A.; Mahmoud, A.R.; Abd-Elhamid, T.H. Ursodeoxycholic acid abrogates gentamicin-induced hepatotoxicity in rats: Role of NF-kappaB-p65/TNF-alpha, Bax/Bcl-xl/Caspase-3, and eNOS/iNOS pathways. Life Sci. 2020, 254, 117760. [CrossRef]

85. Abd-Elhamid, T.H.; Elgamal, D.A.; Ali, S.S.; Ali, F.E.M.; Hassanein, E.H.M.; El-Shoura, E.A.M.; Hemeida, R.A.M. Reno-protective effects of ursodeoxycholic acid against gentamicin-induced nephrotoxicity through modulation of NF-kappaB, eNOS and caspase-3 expressions. Cell Tissue Res. 2018, 374, 367-387. [CrossRef] [PubMed]

86. Lang, S.J.; Schmiech, M.; Hafner, S.; Paetz, C.; Steinborn, C.; Huber, R.; Gaafary, M.E.; Werner, K.; Schmidt, C.Q.; Syrovets, T.; et al. Antitumor activity of an Artemisia annua herbal preparation and identification of active ingredients. Phytomedicine 2019, 62, 152962. [CrossRef] [PubMed]

87. Yuan, H.-D.; Jin, G.-Z.; Piao, G.-C. Protective Effects of the Supernatant of Ethanol Eluate from Artemisia sacrorum Ledeb. against Acetaminophen-Induced Liver Injury in Mice [corrected]. Biol. Pharm. Bull. 2009, 32, 1683-1688. [CrossRef]

88. Deng, X.R.; Liu, Z.X.; Liu, F.; Pan, L.; Yu, H.P.; Jiang, J.P.; Zhang, J.J.; Liu, L.; Yu, J. Holotransferrin enhances selective anticancer activity of artemisinin against human hepatocellular carcinoma cells. J. Huazhong Univ. Sci. Technol. Med. Sci. 2013, 33, 862-865. [CrossRef]

89. Katz, D.; Taylor, D. Parasitic infections of the gastrointestinal tract. Gastroenterol. Clin. N. Am. 2001, 30, 797-815. [CrossRef]

90. Ebert, E.C. Giardia induces proliferation and interferon gamma production by intestinal lymphocytes. Gut 1999, 44, 342-346. [CrossRef] [PubMed]

91. Deplancke, B.; Gaskins, H.R. Microbial modulation of innate defense: Goblet cells and the intestinal mucus layer. Am. J. Clin. Nutr. 2001, 73, 1131S-1141S. [CrossRef]

92. Birchenough, G.M.; Johansson, M.E.; Gustafsson, J.K.; Bergstrom, J.H.; Hansson, G.C. New developments in goblet cell mucus secretion and function. Mucosal. Immunol. 2015, 8, 712-719. [CrossRef]

93. Amat, C.B.; Motta, J.P.; Fekete, E.; Moreau, F.; Chadee, K.; Buret, A.G. Cysteine Protease-Dependent Mucous Disruptions and Differential Mucin Gene Expression in Giardia duodenalis Infection. Am. J. Pathol. 2017, 187, 2486-2498. [CrossRef]

94. Shukla, G.; Sidhu, R.K. Lactobacillus casei as a probiotic in malnourished Giardia lamblia-infected mice: A biochemical and histopathological study. Can. J. Microbiol. 2011, 57, 127-135. [CrossRef]

95. Roskens, H.; Erlandsen, S.L. Inhibition of in vitro attachment of Giardia trophozoites by mucin. J. Parasitol. 2002, 88, 869-873. [CrossRef]

96. Deng, Y.; Liu, Z.; Geng, Y. Anti-allergic effect of Artemisia extract in rats. Exp. Ther. Med. 2016, 12, 1130-1134. [CrossRef] [PubMed]

97. Squire, S.A.; Ryan, U. Cryptosporidium and Giardia in Africa: Current and future challenges. Parasites Vectors 2017, 10, 195. [CrossRef] [PubMed]

98. Bilia, A.R.; Santomauro, F.; Sacco, C.; Bergonzi, M.C.; Donato, R. Essential Oil of Artemisia annua L.: An Extraordinary Component with Numerous Antimicrobial Properties. Evid.-Based Complement Altern. Med. 2014, 2014, 159819. [CrossRef]

99. Elfawal, M.A.; Towler, M.J.; Reich, N.G.; Golenbock, D.; Weathers, P.J.; Rich, S.M. Dried whole plant Artemisia annua as an antimalarial therapy. PLoS ONE 2012, 7, e52746. [CrossRef] [PubMed] 